DOI https://doi.org/10.18551/rjoas.2017-11.40

\title{
COMPENSATION ANALYSIS IN RELATIONSHIP MODERATION BETWEEN TRANSFORMATIONAL LEADERSHIP STYLE AND WORK ENVIRONMENT ON THE EMPLOYEE PERFORMANCE
}

\author{
Tegor*, Umar Husein \\ University of Esa Unggul, Tangerang, Indonesia \\ *E-mail: tigor.belitong@gmail.com
}

\begin{abstract}
The objectives of the research were: 1) to know the influence of transformational leadership style on employee performance, 2) to know the influence of work environment on employee performance, 3) to know the influence of compensation on employee performance. The research used non-hierarchical analysis method or cell means method by using betweensubject of 2x2 and applied Univariate General Linier Model (GLM) procedure. The findings of the research were 1) transformational leadership style does not improve employee performance, 2) work environment improves employee performance, 3) in a good transformational leadership style, low-compensated employee groups improve employee performance, 4) in a poor transformational leadership style, high-compensated employee groups have better performance than low-compensated employee groups, 5) in a good work environment, low compensation does not improve employee performance than high compensation, 6) in a good work environment high compensation does not improve employee performance than a poor work environment.
\end{abstract}

\section{KEY WORDS}

Compensation, transformational leadership style, work environment, employee.

In an organization, leadership is very important. Because organization with a good leadership will be easily to build the foundation of trust in their members, while an organization that does not have a good leadership will find it difficult to gain the trust of their members. In addition, leadership qualities can encourage someone to get a successful and happy career. Job satisfaction comes from leadership. However, many employees feel that many leaders fail to develop leadership skills and the main reason for employee failure is the weak leadership.

In leadership relationship, one respects others in two ways. First, a leader respects their employees unconditionally. The appreciation is not based on outward traits, such as position, education, or economic status but acknowledges one's contribution, both actual and potential contribution. It does not mean that the achievement of a person in particular position or level of education is not appreciated, but it does not let the respect/appreciation to a person is hindered because of particular position or level of education. Second, some people think individuals with certain educational qualifications are the most worthy of respect/appreciation. It is an example of an award based on the outward traits. A leader is fully aware that this situation may lead to a change of role, which places the leader in an employee/being-led position.

Transformational Leadership Style on Employee Performance. According to Shea (1999), in an article entitled The Effects of Leadership Style on Performance Improvement on a Manufacturing Task, with a sample of 65 operation management students, the result of the research showed that individuals work under caring leader outperform to individuals qualitatively work under charismatic leader and leadership structure in the first experiment. Those who work under the caring leader also outperform to individuals qualitatively work under the leadership structure in the second experiment. This study supports that leadership style does affect the improvement of performance time over time.

Anit (2006), in a research entitled The Effects of Leadership Style and Team Process on Performance and Innovation in Functionally Heterogeneous Teams, focused on 
participative leadership style with a sample of 140 nurse teams, and the result of the research indicated a positive influence of participative leadership style, which subsequently may encourage team innovation. However, this leadership style decreases team's performance role. Fernandes and Awamleh (2009), in an article entitled The Impact of Transformational and Transactional Leadership Style on Employee's Satisfaction and Performance: An Empirical Test in a Multicultural Environment asserted that the transformational leadership style of the managers will improve employee job satisfaction. As the managers operationalize charisma and take advantage of inspiration, individual considerations, and intellectual stimulation, they get positive reactions from the employees. It seems that such transformational qualities certainly stimulate higher levels of employees ' needs and result in a higher sense of satisfaction. Biswas (2009), in an article entitled $H R$ Practices as a Mediator between Organizational Culture and Transformational Leadership: Implications for Employee Performance presented the results of research in which culture and leadership are significant predictors of employee performance and their intents to quit. The results also show that the practice of human resources is an important mediator in transmitting the influence of predictor variables to the criterion variable.

Work Environment on Employee Performance. Ganapathi and Prasasd (2008), in an article entitled Effects of Working Environment on the Performance of Executives, with a sample of 200 executive employees working in various organizations, affirmed that the work environment positively affects the employee performance and plays an important role in improving individual performances and organizations as a whole. Meanwhile, according to Malik, et al. (2011) in an article entitled A Study of Work Environment and Employees' Performance in Pakistan, examining the object of 115 employees of telecommunication companies in Pakistan, also explained the positive influence between work environment and employee performance.

Compensation on Employee Performance. Sinclair (2004) in the article entitled The Effect of Director Compensation on Firm Performance explained the relationship between the compensation of the stock-based director and the performance of the company. Generally, stock compensation is negatively related to the performance of the company. However, to a higher extent, stock compensation has a positive effect on the performance of the company which indicates that if the directors are adequately compensated, it will have a positive effect on the performance of the company. Guo, et al. (2006) in the article entitled Stock Bonus Compensation and Firm Performance in Taiwan explained the evidence of positive findings in Taiwan between the number of stock bonuses and the performance of the company. It is also found in large companies with high growth opportunities; they tend to adopt stock bonuses. Companies with well-designed bonus compensations can produce better performance as well.

Shieh (2008) in the article entitled Effect of Corporate Compensation on Organizational Performance, with a sample of 600 employees in Taiwan, explained the significant relationship between the company's compensation and organizational performance. While Blazovich (2013) in the article entitled Team Identity and Performance-Based Compensation Effects on Performance explained that combinations based on individuals and teams in which based on performance results comparable to strong and weak team identities, showed that lower productivity levels-related to weak team identity-can be overcome with performance-based compensation.

The Research Gap of Transformational Leadership Style on Employee Performance. Started from Warrick (1973) showed that democratic leaders are more effective than other leaders in terms of Employee Performance Effectiveness and leaders with high adaptive skills tend to be more effective than low leadership adaptability. Finally, the findings revealed that Professional Leaders are consistently more effective in terms of the Employee Performance Effectiveness of all leaders. Followed by Shea (1999) explained that individuals work under caring leader outperform to individuals qualitatively work under charismatic leader and leadership structure in the first experiment. Those who work under the caring leader also outperform to individuals qualitatively work under the leadership structure in the 
second experiment. This study supports that leadership style does affect the improvement of performance time over time.

Somech (2006) explained the positive influence of participative leadership style, which subsequently may encourage team innovation. However, this leadership style decreases the team's performance role. Followed by Fernandes and Awamleh, (2009) affirmed that the transformational leadership style of managers will improve employee job satisfaction. When managers operationalize charisma and take advantage of inspiration, individual considerations, and intellectual stimulation, they get positive reactions from the employees. It seems that such transformational qualities do stimulate higher levels of employees ' needs and result in a higher sense of satisfaction. Biswas (2009) showed the results of the research that culture and leadership are significant predictors of employee performance and their intents to quit. The results also showed that the practice of human resources is an important mediator in transmitting the influence of predictor variables to the criterion variable.

Work Environment Gap on Employee Performance. Ganapathi and Prasasd (2008) in an article entitled Effects of Working Environment on the Performance of Executives, with a sample of 200 executives working in various organizations, affirmed that work environment, positively affects the employee performance and plays an important role in improving the performance of individuals and organizations as a whole. Meanwhile, according to Malik, et al. (2011) in an article entitled A Study of Work Environment and Employees' Performance in Pakistan, examining the object of 115 employees of telecommunication companies in Pakistan, also explained the positive influence between work environment and employee performance.

Compensation Gap on Employee Performance. Sinclair (2004) explained the relationship between the compensation of the stock-based director and the performance of the company. Generally, stock compensation is negatively related to the performance of the company. However, to a higher extent, stock compensation has a positive effect on the performance of the company which indicates that if the directors are adequately compensated, it will have a positive effect on the performance of the company. Followed by Guo, et al. (2006), there was evidence of positive findings in Taiwan between the amount of stock bonus and the performance of the company. It is also found in large companies with high growth opportunities in which tend to adopt stock bonuses. Companies with welldesigned bonus compensations can produce better performance as well. Shieh (2008) also explained a significant relationship between the company's compensation with organizational performance.

Meanwhile, Blazovich (2013) revealed that combinations based on individuals and teams in which based on performance results comparable to strong and weak team identities, showed that lower productivity levels-related to weak team identity-can be overcome with performance-based compensation. Another model, developed by Akhter, et al. (2016), explained that compensation plays an important role in training recruitment and retention; the research revealed that in some industries, there are findings or discrimination on the appointment of employees. In fact, it is possible for Engro Food practitioners and employees. Industry leaders reduce turnover rates and improve employee performance. Because retaining experienced employees is much better than hiring new people and training them.

\section{METHODS OF RESEARCH}

Mean-Cells Model. This research used non-hierarchical or mean-cells method analysis by using between-subject of 2x2 and applied the procedure of Univariate General Linier Model (GLM). In data analysis, basically it aimed to study the difference of mean of response variable or indicator of certain problem between individual groups including in conducting hypothesis testing about the difference in population under review. The mean-cells function has a reciprocal relationship with the mean-cells table, namely the table which presents the mean (average) of the dependent variable or indicator of a particular problem by a factor or multifactor (Kuludong, 2010). 
General Linear Model (GLM) Univariate Method. This mean-cells test applies the General Linier Model (GLM) procedure to perform a null hypothesis testing in which some groups of data samples have the same average grade/score. The application of the General Linier Model (GLM) Univariate procedure aimed to conduct hypothesis testing on: 1) homogeneity; 2) the difference or similarity of all the observed mean-cells parameters; 3 ) the differences in some pairs of certain mean-cells parameters; 4) the influence of the main and interaction factors on response variables, especially those that cannot be tested by applying the One-Way ANOVA procedure (Kuludong 2016). Univariate General Linear Model Procedure (GLM), in the use of statistical software, is necessarily to analyze General Linear Model Univariate, then the dependent variable and fixed factor are included which are the coding of transformational leadership style, work environment and compensation variable, then it is analyzed in an estimate parameter in statistical calculations.

Sampling and Data Collection Techniques. In this research, the researcher used simple random sampling. The sampling process is conducted by giving equal opportunity to each member of the population to become a sample member. So, the process of selecting the $n$ sample from the $\mathrm{N}$ population is conducted randomly. There are two ways: using Cointoss or using Random Numbers. When the population is small, it can be conducted by drawing "Cointoss". But if the population is large, it is necessary to use the label of "Random Numbers". In this research, the sampling technique used simple random sampling; the number of respondents who were going to be sample is 120 respondents. In this study, the researcher used the questionnaire as a data collection technique. Questionnaire is a technique of collecting data from consumers with a set of questions or statements that must be answered by respondents; in this case the respondents are the employee of PT. Seliu Multi Persada. In answering these statements and questions, Likert scale was used as the level of importance; according to Sugiyono (2013), Likert scale is used to measure attitude, opinion and perception of a person or group of social phenomena that occur. In Likert scale, the measured variables are elaborated by sub-variables. The sub-variables are used as indicators and then these indicators become the starting point for the preparation of the instrument items in the form of statements and questions.

\section{RESULTS AND DISCUSSION}

Median Split of Transformational Leadership Style and Compensation. The determination of median split values of transformational leadership style, work environment, compensation, and employee performance variables aims to divide groups within cells of the respondents being studied. Determining the median split was obtained from 120 respondents being studied with valid results and the note of each respondent value; transformational leadership style variable is abbreviated to GKT, work environment is abbreviated to LK, compensation variable is abbreviated to KOMP, and employee performance variable is abbreviated to $\mathrm{KK}$; and then median split calculation was performed by using statistical software. After the median split number is obtained from the transformational leadership style and the compensation variables, it can be seen that the respondent may be included into a good leadership style with the number 1 ; or if the value of the respondent variable is lower than the median split or the transformational leadership style is poor, the number is 2 . As for compensation variable, to know the respondents being studied to be included in the group of high compensation perception with the number 1 if the value of the respondent variable is higher than the median split and low compensation with the number 2 if the value of the respondent variable is lower than the median split.

In this study, from 120 respondents, 60 respondents were found having a good leadership style and 60 respondents having poor leadership style. It is followed by 60 respondents having high compensation and 60 respondents having low compensation as shown in table 1.

The results of this test indicate that the variables being studied have no influence in determining the level of employee performance. Hypothesis testing uses the $F$ test statistic at "GKTCODE" line, where F0 $=0.042$ (Sig. 0.838) with the free degree of $1 / 116$. It indicates 
the rejection of $\mathrm{H} 1$, so it can be concluded that the data do not support the proposed hypothesis. It shows that a good transformational leadership style does not affect employee performance.

Table 1 - Statistics of Median Split

\begin{tabular}{|c|c|c|c|c|}
\hline & - & GKT code & KOMP code & KK code \\
\hline \multirow{2}{*}{$\mathrm{N}$} & Valid & 120 & 120 & 120 \\
\hline & Missing & 0 & 0 & 0 \\
\hline & Median & -.0291278 & -.0876468 & .1148187 \\
\hline
\end{tabular}

Table 2 - Between-Subject Factors

\begin{tabular}{|c|c|c|c|}
\hline \multicolumn{2}{|c|}{-} & Value Label & N \\
\hline \multirow{2}{*}{ GKT MEDIAN } & 1,00 & Good & 60 \\
\cline { 2 - 4 } & 2,00 & Poor & 60 \\
\hline \multirow{2}{*}{ KOMP MEDIAN } & 1,00 & High & 60 \\
\cline { 2 - 4 } & 2,00 & Low & 60 \\
\hline
\end{tabular}

Table 3 - Parameter Test of Between-Subject Effects

Dependent Variable: Employee Performance

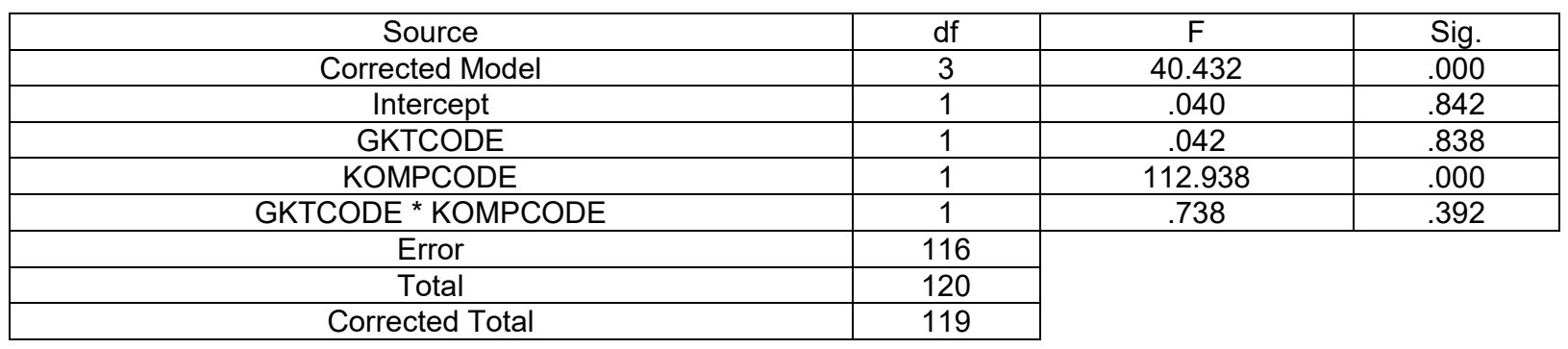

Table 4 - Estimate Parameter Design A (AB)

Dependent Variable: Employee Performance

\begin{tabular}{|c|c|c|c|c|c|}
\hline Parameter & Description & $\mathrm{B}$ & $\beta$ & $\mathrm{t}$ & Sig. \\
\hline Intercept & - & -.676 & $\beta 0$ & -5.809 & .000 \\
\hline$[$ GKTCODE=1.00] & GKT $=1$ & -.087 & $\beta 1$ & -.463 & .645 \\
\hline$[$ GKTCODE=2.00] & GKT $=2$ & $0^{\mathrm{a}}$ & - & - & - \\
\hline$[$ KOMPCODE=1.00] & KOMP $=1$ & 1.299 & $\beta 2$ & 6.907 & .000 \\
\hline$[\mathrm{KOMPCODE=2.00]}$ & $\mathrm{KOMP}=2$ & $0^{\mathrm{a}}$ & - & - & - \\
\hline$\left[\right.$ GKTCODE=1.00] ${ }^{*}[\mathrm{KOMPCODE}=1.00]$ & - & .228 & $\beta 3$ & .859 & .392 \\
\hline
\end{tabular}

Based on the above table, can be obtained the following equation of regression model:

$$
Y=\beta 0+\beta 1(G K T=1)+\beta 2(K O M P=1)+\beta 3(G K T=1)(K O M P=1)+\varepsilon \text { 。 }
$$

Description:

GKT = 1 is a good transformational leadership style;

$\mathrm{GKT}=2$ is a poor transformational leadership style;

$\mathrm{KOMP}=1$ is high compensation;

$\mathrm{KOMP}=2$ is low compensation.

Table 5 - Intercept Parameter $\beta i$ Design A (AB)

\begin{tabular}{|c|c|c|c|c|}
\hline- & GKT $=1$ (Good) & GKT = 2 (Poor) & Difference & Hypothesis \\
\hline $\begin{array}{c}\text { KOMP }=1 \\
(\text { High })\end{array}$ & $\beta 0+\beta 1+\beta 2+\beta 3$ & $\beta 0+\beta 2$ & $\beta 1+\beta 3$ & - \\
\hline $\begin{array}{c}\text { KOMP }=2 \\
(\text { Low })\end{array}$ & $\beta 0+\beta 1$ & $\beta 0$ & $\beta 1$ & H3a \\
\hline Difference & $\beta 2+\beta 3$ & $\beta 2$ & $\beta 3$ & - \\
\hline Hypothesis & - & $\mathrm{H} 3 \mathrm{~b}$ & $\mathrm{H} 3 \mathrm{c}$ & - \\
\hline
\end{tabular}


The contents of each cell are the intercepts so that the difference is the difference between the intercepts.

Table 6 - Intercept Value

\begin{tabular}{|c|c|c|c|}
\hline$\beta 0$ & $\beta 1$ & $\beta 2$ & $\beta 3$ \\
\hline-0.676 & $-0,087$ & 1.299 & 0.288 \\
\hline
\end{tabular}

Table 7 - Intercept Value Calculation

\begin{tabular}{|c|c|c|c|}
\hline- & GKT $=1$ & GKT $=2$ & Difference \\
\hline KOMP $=1$ & 0.824 & 0.623 & 0.201 \\
\hline KOMP = 2 & -0.763 & -0.676 & -0.087 \\
\hline Difference & 1.587 & 1.299 & 0.288 \\
\hline
\end{tabular}

Description:

GKT = 1 is a good transformational leadership style;

GKT $=2$ is a poor transformational leadership style;

$\mathrm{KOMP}=1$ is high compensation;

$\mathrm{KOMP}=2$ is low compensation.

Table 8 - Summary Results, Significant Effect between Subjects

Dependent Variable: Employee Performance

\begin{tabular}{|c|c|c|}
\hline Parameter & $\beta$ & Sig. \\
\hline Intercept & $\beta 0$ & .000 \\
\hline$[$ GKTCODE=1.00] & $\beta 1$ & .645 \\
\hline$[$ KOMPCODE=1.00] & $\beta 2$ & .000 \\
\hline$\left[\right.$ GKTCODE=1.00] ${ }^{*}[$ KOMPCODE=1.00] & $\beta 3$ & .392 \\
\hline
\end{tabular}

Table 9 - Results of $\beta 1, \beta 2$, and $\beta 3$

\begin{tabular}{|c|c|}
\hline & Description \\
\hline$\beta 1$ & $\begin{array}{l}\text { Especially for groups of employees with a perception of a good transformational leadership style, even with } \\
\text { low compensation, it will improve employee performance. The intercept calculation table shows that there is } \\
\text { a difference between [COMP }=1][\mathrm{GKT}=2] \text { and }[\mathrm{KOMP}=2] \text { [GKT }=2] \text { on employee performance; the result } \\
\text { is } \beta 1 \text {. } \\
\text { The significant level at } \beta 1 \text { is } 0.645 \text {; it means the significant value }>0.05 \text { so } \beta 1 \text { is not significant. }\end{array}$ \\
\hline$\beta 2$ & $\begin{array}{l}\text { Especially for groups with a perception of a poor transformational leadership style, highly compensated } \\
\text { groups perform better than the low compensated groups. The intercept calculation table shows that there is } \\
\text { a difference between }[\mathrm{KOMP}=2][\mathrm{GKT}=1] \text { and }[\mathrm{KOMP}=2] \text { [GKT }=2] \text { on employee performance; the result } \\
\text { is } \beta 2 \text {. } \\
\text { The significant level at } \beta 2 \text { is } 0.000 \text {. So, } \beta 2 \text { is significant. }\end{array}$ \\
\hline$\beta 3$ & $\begin{array}{l}\text { Especially for a group with a perception of a good transformational leadership style, high compensation is no } \\
\text { more satisfied than those who receive low compensation. The intercept calculation table shows that there is } \\
\text { a difference between [COMP }=1] \text { [GKT }=1] \text {, [KOMP }=1] \text { [GKT }=2] \text { and }[K O M P=2][G K T=1] \text {, [KOMP }=2] \\
{[G K T=2] \text { on employee performance; the result is } \beta 3 \text {. }} \\
\text { The significant level of } \beta 3 \text { is } 0.392 \text {; it means the significant value }>0.05 \text {. So, } \beta 3 \text { is not significant. }\end{array}$ \\
\hline
\end{tabular}

Source: Test results on data analysis tool.

Median Split Variable of Work Environment and Compensation. Determination of the mean or median split value of work environment and compensation variables aims to divide the group in the cells of the respondents being studied. The determination of median split was obtained from 120 respondents with valid results and the value of each respondent. Work environment variable is changed to LK, compensation is changed to KOMP, and employee performance is changed to KK. Then median split calculations was conducted by using statistical software.

After the median split is obtained from work environment and the compensation variables, it can be seen that the respondents are included in a good work environment group with number 1 (if the value of respondent's variable is higher than the median split) or included in a poor work environment with number 2 (if the value of respondent's variable is 
lower than the median split); and for compensation variable, the respondents being studied are included in high compensation perception group with number 1 (if the value of respondent variable is higher than median split) and low compensation perception with number 2 (if the value of respondent variable is lower than median split).

From 120 respondents of the research, 60 respondents were at good work environment, 60 respondents were at bad work environment, and 60 respondents with high compensation, and 60 respondents with low compensation as shown in the following table:

Table 10 - Statistics of Median Split

\begin{tabular}{|c|c|c|c|c|}
\hline \multicolumn{2}{|c|}{-} & Lkcode & KOMPcode & KKcode \\
\hline \multirow{2}{*}{$\mathrm{N}$} & Valid & 120 & 120 & 120 \\
\cline { 2 - 5 } & Missing & 0 & 0 & 0 \\
\hline \multicolumn{2}{|c|}{} & .1059118 & -.0876468 & .1148187 \\
\hline
\end{tabular}

Table 11 - Between-Subjects Factors

\begin{tabular}{|c|c|c|c|}
\hline \multicolumn{2}{|c|}{-} & Value Label & N \\
\hline \multirow{2}{*}{ LKCODE } & 1,00 & Good & 60 \\
\cline { 2 - 4 } & 2,00 & Poor & 60 \\
\hline \multirow{2}{*}{ KOMPCODE } & 1,00 & High & 60 \\
\cline { 2 - 4 } & 2,00 & Low & 60 \\
\hline
\end{tabular}

Table 12 - Parameter Test of Between-Subject Effects

Dependent Variable: Employee Performance

\begin{tabular}{|c|c|c|c|}
\hline Source & df & F & Sig. \\
\hline Corrected Model & 3 & 55.534 & .000 \\
\hline Intercept & 1 & .765 & .384 \\
\hline LKCODE & 1 & 21.515 & .000 \\
\hline KOMPCODE & 1 & 28.182 & .000 \\
\hline LKCODE ${ }^{*}$ KOMPCODE & 1 & 1.561 & .214 \\
\hline Error & 116 & \multicolumn{1}{|}{} \\
\cline { 1 - 2 } Total & 120 & \multicolumn{1}{|}{} \\
\cline { 1 - 2 } Corrected Total & 119 &
\end{tabular}

The results of this test indicate that the variables being studied have an influence in determining the level of employee performance. Hypothesis testing by using the F-Test statistic at LKCODE row where F0 $=21,515$ (Sig. 000), with degrees of freedom of 1/116. It indicates a rejection of $\mathrm{H} 0$, so it can be concluded that the data support the proposed hypothesis. It shows that a good working environment affects employee performance. It means that the better a work environment, the higher the employee performance.

Table 13 - Estimate Parameter Design A (AB)

Dependent Variable: Employee Performance

\begin{tabular}{|c|c|c|c|c|c|}
\hline Parameter & Description & $\mathrm{B}$ & $\beta$ & $\mathrm{t}$ & Sig. \\
\hline Intercept & - & -0.856 & $\beta 0$ & -9.423 & 0.000 \\
\hline$[\mathrm{LKCODE}=1.00]$ & $\mathrm{LK}=1$ & 0.977 & $\beta 1$ & 4.163 & 0.000 \\
\hline$[\mathrm{LKCODE}=2.00]$ & $\mathrm{LK}=2$ & 0 & - & - & - \\
\hline$[\mathrm{KOMPCODE}=1.00]$ & $\mathrm{KOMP}=1$ & 1.088 & $\beta 2$ & 4.637 & 0.000 \\
\hline$[\mathrm{KOMPCODE}=200]$ & $\mathrm{KOMP}=2$ & 0 & & - & - \\
\hline$[\mathrm{LKCODE}=1.00]^{*}[\mathrm{KOMPCODE}=1.00]$ & - & -0.414 & $\beta 3$ & -1.249 & 0.214 \\
\hline
\end{tabular}

Based on the above table, can be obtained the following equation of regression model:

$$
Y=\beta 0+\beta 1(L K=1)+\beta 2(K O M P=1)+\beta 3(L K=1)(K O M P=1)+\varepsilon \text { 。 }
$$

Description:

LK $=1$ is a good working environment; 
$\mathrm{LK}=2$ is a poor work environment;

$\mathrm{KOMP}=1$ is high compensation;

$\mathrm{KOMP}=2$ is low compensation.

Table 14 - Intercept Parameter $\beta$ i Design A (AB)

\begin{tabular}{|c|c|c|c|c|}
\hline- & $\begin{array}{l}\text { LK = } 1 \\
\text { (Good) }\end{array}$ & $\begin{array}{l}\mathrm{LK}=2 \\
\text { (Poor) }\end{array}$ & Difference & Hypothesis \\
\hline $\begin{array}{c}\text { KOMP = } 1 \\
(\text { High })\end{array}$ & $\beta 0+\beta 1+\beta 2+\beta 3$ & $\beta 0+\beta 2$ & $\beta 1+\beta 3$ & - \\
\hline $\begin{array}{c}\mathrm{KOMP}=2 \\
(\text { Low })\end{array}$ & $\beta 0+\beta 1$ & $\beta 0$ & $\beta 1$ & $\mathrm{H} 4 \mathrm{a}$ \\
\hline Difference & $\beta 2+\beta 3$ & $\beta 2$ & $\beta 3$ & - \\
\hline Hypothesis & - & $\mathrm{H} 4 \mathrm{~b}$ & $\mathrm{H} 4 \mathrm{c}$ & - \\
\hline
\end{tabular}

The contents of each cell are the intercepts so that the difference is the difference between the intercepts.

Table 15 - Intercept Value

\begin{tabular}{|c|c|c|c|}
\hline$\beta 0$ & $\beta 1$ & $\beta 2$ & $\beta 3$ \\
\hline-0.856 & 0.977 & 1.088 & -0.414 \\
\hline
\end{tabular}

Source: Test results on data analysis tool.

Table 16 - Calculation Intercept Value

\begin{tabular}{|c|c|c|c|}
\hline- & LK = 1 & LK = 2 & Difference \\
\hline KOMP =1 & 0.795 & 0.232 & 0.563 \\
\hline KOMP = 2 & 0.121 & -0.856 & 0.977 \\
\hline Difference & 0.647 & 1.088 & -0.414 \\
\hline
\end{tabular}

Source: Test results on data analysis tool.

Notes: $L K=1$ is a good working environment; $L K=2$ is a poor work environment; $K O M P=1$ is high compensation; $K O M P=2$ is low compensation.

Table 17 - Summary Results, Significant Effect between Subjects

Dependent Variable: Employee Performance

\begin{tabular}{|c|c|c|}
\hline Parameter & $\beta$ & Sig. \\
\hline Intercept & $\beta 0$ & 0,000 \\
\hline$[$ LKCODE=1,00] & $\beta 1$ & 0,000 \\
\hline$[$ KOMPCODE=1,00] & $\beta 2$ & 0,000 \\
\hline$[\mathrm{LKCODE}=1,00]^{*}[\mathrm{KOMPCODE}=1,00]$ & $\beta 3$ & 0,214 \\
\hline
\end{tabular}

Source: Test results on data analysis tool.

Table 18 - Results of $\beta 1, \beta 2$, and $\beta 3$

\begin{tabular}{|c|c|}
\hline- & Description \\
\hline$\beta 1$ & $\begin{array}{l}\text { Especially for a group of employees with a perception of good work environment, getting poor compensation } \\
\text { does not improve employee performance than a well-compensated group of employees. The intercept } \\
\text { calculation table shows the difference between the [COMP = 1] [LK = 2] and [KOMP = 2] [LK }=2] \text { on the } \\
\text { employee performance; the result is } \beta 1 \text {. The significant level at } \beta 1 \text { is } 0.000 \text {; it means that the significant } \\
\text { value }<0.05 \text {. So, } \beta 1 \text { is significant. }\end{array}$ \\
\hline$\beta 2$ & $\begin{array}{l}\text { Especially for groups of employees with a perception of high compensation, poor work environment } \\
\text { improves the employee performance more than the group of low compensated employee. The intercept } \\
\text { calculation table shows that there is a difference between [KOMP }=2 \text { ] [ } \mathrm{LK}=1] \text { and [KOMP }=2 \text { ] [LK }=2 \text { ] on } \\
\text { employee performance; the result is } \beta 2 \text {. The significant level at } \beta 2 \text { is } 0.000 \text {; it means that the significant } \\
\text { value }<0.05 \text {. So, } \beta 2 \text { is significant. }\end{array}$ \\
\hline$\beta 3$ & $\begin{array}{l}\text { Especially for a good working environment, a group of employees with good compensation does not improve } \\
\text { the employee performance than in a poor work environment. The intercept calculation table shows there is a } \\
\text { difference between [KOMP }=1] \text { [ }[\mathrm{LK}=1] \text {, [KOMP }=2][\mathrm{LK}=2] \text { on employee performance; the result is } \beta 3 \text {. } \\
\text { The significant level at } \beta 3 \text { is } 0.214 \text {; it means that the significant value }>0.05 \text {. So, } \beta 3 \text { is not significant. }\end{array}$ \\
\hline
\end{tabular}


Table 19 - Hypothesis Testing of Research Model

\begin{tabular}{|c|c|c|c|}
\hline Hypothesis & Hypothesis Statements & $\begin{array}{c}\text { Value } \\
\text { of Sig. }\end{array}$ & Description \\
\hline $\mathrm{H} 1$ & The transformational leadership style improves employee \\
performance. & 0.838 & $\begin{array}{c}\text { The data do not } \\
\text { support the } \\
\text { hypothesis }\end{array}$ \\
\hline $\mathrm{H} 2$ & Work environment improves employee performance. & 0.000 & $\begin{array}{c}\text { The data support the } \\
\text { hypothesis }\end{array}$ \\
\hline $\mathrm{H} 3 \mathrm{a}$ & $\begin{array}{c}\text { Especially for a good transformational leadership style, the group } \\
\text { of employees who get low compensation will improve their } \\
\text { employee performances. }\end{array}$ & 0.645 & $\begin{array}{c}\text { The data do not } \\
\text { support the } \\
\text { hypothesis }\end{array}$ \\
\hline $\mathrm{H} 3 \mathrm{~b}$ & $\begin{array}{c}\text { Especially for a poor transformational leadership styles, high- } \\
\text { compensated employee groups perform better than low- } \\
\text { compensated employees. }\end{array}$ & 0.000 & $\begin{array}{c}\text { The data support the } \\
\text { hypothesis }\end{array}$ \\
\hline $\mathrm{H} 3 \mathrm{c}$ & $\begin{array}{c}\text { Especially for a good transformational leadership style, high- } \\
\text { compensated employee groups are no more satisfied than low- } \\
\text { compensated employee groups. }\end{array}$ & 0.392 & $\begin{array}{c}\text { The data do not } \\
\text { support the } \\
\text { hypothesis }\end{array}$ \\
\hline $\mathrm{H} 4 \mathrm{a}$ & $\begin{array}{c}\text { Especially for a good work environment, low compensation does } \\
\text { not improve employee performance compared with high } \\
\text { compensation. }\end{array}$ & 0.000 & $\begin{array}{c}\text { The data support the } \\
\text { hypothesis }\end{array}$ \\
\hline $\mathrm{H} 4 \mathrm{~b}$ & $\begin{array}{r}\text { Especially for high compensation, poor working environment } \\
\text { improves performance compared to low compensation. }\end{array}$ & 0.000 & $\begin{array}{c}\text { The data support the } \\
\text { hypothesis }\end{array}$ \\
\hline $\mathrm{H} 4 \mathrm{c}$ & $\begin{array}{c}\text { Especially for a good working environment, high compensation } \\
\text { does not improve employee performance compared with poor } \\
\text { work environment. }\end{array}$ & 0.214 & $\begin{array}{c}\text { The data do not } \\
\text { support the } \\
\text { hypothesis }\end{array}$ \\
\hline
\end{tabular}

\section{DISCUSSION OF RESULTS}

Transformational Leadership Style Improves Employee Performance. In the results of hypothesis testing, it is found that the analysis does not support $\mathrm{H} 1$ hypothesis; transformational leadership style improves employee performance with Sig. value of 0.838 $(>0.05)$. The results of this study are not in line or inconsistent with the result of the research conducted by Fernandes and Awamleh (2009) where they asserted that when a manager/leader makes use of inspiration, individual consideration, and intellectual stimulation, they will get a positive reaction from the employees. It seems that such transformational qualities do stimulate a higher level of employee's demand and result in a sense of satisfaction and a high level of performance. So, in this hypothesis, even though an employee has a high level of performance, it does not guarantee that the employee will be rewarded. With the results of the above hypothesis, the researchers concluded that in the manufacturing industry, employees do not require leadership style from their leaders, but employee performance is more required on the skill or ability of the employee.

Work Environment Improves Employee Performance. In the results of hypothesis testing, it is found that the analysis supports $\mathrm{H} 2$ hypothesis; the work environment improves employee performance with Sig. value of $0.000(<0.05)$. The results of this study are in line with the research conducted by Ganapathi and Prasad (2008), they confirmed that the work environment plays an important role in improving the performance of individual employees and the organization as a whole.

The conclusion of this hypothesis is that an employee who is in a good and comfortable work environment and is supported by colleagues and other supported facilities will improve the performance of the employees.

Especially for a Good Transformational Leadership Style, Group of Employees Getting Low Compensation Improves Employee Performance. In the hypothesis testing of $3_{\mathrm{a}}$, it is found that the result of analysis does not support $\mathrm{H}_{3 a}$ hypothesis, especially for a good leadership style; group of employees getting low compensation will improve employee performance, with Sig. value of $0.645(>0.05)$. Although a leader applies a transformational leadership style to the employees, it does not affect the employee performance. Because employees expect more high compensation rewards, because with higher compensation will further improve the employee's performance. Leaders are expected to pay more attention 
and review the level of compensation given to employees in accordance with employee performance and to have a different style of leadership to the employees.

Especially for a Poor Transformational Leadership Style, Highly Compensated Employees are better than Low-compensated Employees. In the result of hypothesis testing of $3_{b}$, it is found that the result of analysis supports $\mathrm{H}_{3 \mathrm{~b}}$ hypothesis, especially for poor transformational leadership style; high compensation employee performs better than low compensation employee, with Sig. value of $0.000(<0.05)$. The results of this hypothesis support the research conducted by Yukl (2009) stated that by having transformational leadership, the employees will have trust, admiration, and respect for the leadership, and they will do more than what is expected. Leaders with transformational leadership styles transform and motivate the employees by making them more aware to the importance of the end result of a job, encouraging them to transcend their own personal interests for the benefit of the organization or team, and activating their higher order needs. By providing high compensation, it will make the employees more motivated in improving their performances, even though transformational leadership style is run by poor leaders, it does not affect the level of employee performance.

Especially for a Good Transformational Leadership Style, highly compensated employees are no more satisfied than low-compensated employees. In the result of hypothesis testing of $3_{c}$, it is found that the analysis result does not support $\mathrm{H}_{3 c}$ hypothesis, especially for a good leadership style; employees getting high compensation is no more satisfied than employees who get low compensation, with the Sig. value of $0.392(>0.05)$. The results of this hypothesis are in contrast to the results of the research conducted by Fernandes and Awamleh (2009), they asserted that the transformational leadership style applied by leaders will improve employee work satisfaction, and it seems that such transformational qualities stimulate higher levels of employees' higher satisfaction. In this research, there is dissatisfaction experienced by the employees even though they get high compensation.

Especially for a Good Work Environment, Low Compensation Does Not Improve Employee Performance Compared with Higher Compensation. In the result of hypothesis testing of $4_{a}$, it is found that the analysis result supports $\mathrm{H}_{4 a}$ hypothesis, especially for a good work environment; low compensation does not improve employee performance compared with high compensation, with Sig. value of $0.00(<0.05)$. The results of this hypothesis are in line with the research conducted by Milkovich and Newnan (2005), stated that the payroll system can translate strategy into practice to achieve the basic objectives of the company, including efficiency, fairness and compliance with government and legal requirements. Efficiency is expressed as performance improvement, quality improvement, satisfying the consumers and stakeholders as well as cost control. Meanwhile, the performance of an employee plays an important role for an organization because it contributes to the achievement of the company objectives.

Especially for a High Compensation, Poor Work Environment Improves Employee Performance Compared with Low Compensation. In the result of hypothesis testing of $4_{b}$, it is found that the result of the analysis supports $\mathrm{H}_{4 b}$ hypothesis, especially for a high compensation; poor work environment improves employee performance more than low compensation with Sig. value of $0.00(<0.05)$. This hypothesis supports the research conducted by Philip, et al. (2010) who revealed that a fair compensation can spur the employee participation so that employees can work with full responsibility and have work participation towards the company. An employee who has worked with full responsibility and high dedication to the company will certainly expect the award, no matter how small the award will be very beneficial for these employees in motivating other employees in improving their performances.

Especially for a Good Work Environment, Higher Compensation Does Not Improves Employee Performance Compared with Poor Work Environment. In the result of hypothesis testing of $4_{c}$, it is found that the result of the analysis does not support $\mathrm{H}_{4 c}$ hypothesis, especially for a good work environment; high compensation does not improve employee performance compared with poor work environment, with Sig. value of $0.214(>0.05)$. The 
results of this hypothesis support the statement of Carnahan, et al. (2010), said the lack of attention of the companies in providing fair and reasonable compensation to employees and inadequate work environment will impact on the declining performance of the employees. Higher compensation provided by the company does not necessarily improve the employee performance. In addition, a work environment that does not support these employees in doing their work will further make the employee performance even worse.

\section{CONCLUSION}

This study examines the influence of leadership style and work environment on employee performance that is moderated by compensation at PT. Seliu Multi Persada Tangerang. This research used non-hierarchical method or mean-cells method analysis by using between-subject of $2 \times 2$ and applied the procedure of Univariate General Linier Model (GLM). The transformational leadership style does not improve employee performance (the first hypothesis is not supported). Because, the transformational leadership style that is shown or implemented by the leadership of PT. Seliu Multi Persada does not affect employee performance. Work environment will improve employee performance. The better work environment will further enhance employee performance (second hypothesis is supported). The work environment gives a big impact on employee performance. A good working environment will provide a sense of security for employees in performing or carrying out their duties. A third conclusion from the results of this research found that especially for a good transformational leadership style groups, groups of employees getting low compensation will improve employee performance (the third hypothesis is not supported). Even though a leader has a good transformational leadership style, it does not improve employee performance; in addition, with low compensation.

For a poor transformational leadership style, high-compensated employee groups perform better than low-compensated employees (the fourth hypothesis is accepted). Employees at PT. Seliu Multi Persada do not measure their level of performance loyalty from the leadership style implemented by a leader, but they measure with a high level of compensation. The fifth conclusion of the results of this research found that especially for good transformational leadership styles, high-compensated employee groups are not satisfied more than low-compensated employee groups (the fifth hypothesis is rejected). The higher levels of compensation the company provides to employees, it will improve the employee's performance.

In a good work environment, low compensation does not further improve employee performance compared to high compensation (the sixth hypothesis is accepted). By having a good working environment provided by the company, providing a sense of security to employees in the work and giving a low compensation, it will not necessarily improve the performance of employees in the company. The seventh conclusion from the results of this research found that especially for high compensation, poor work environment further improves employee performance compared to low compensation (the seventh hypothesis is accepted). In spite of poor work environment, when the compensation provided by the company is high it will improve employee performance. In a good work environment, high compensation does not improves performance more than a poor work environment (the eighth hypothesis is rejected). The employee performance is measured not by how high the level of compensation, but with how a poor work environment will improve employee performance.

\section{REFERENCES}

1. Akhter, N., ljaz, M., Siddiqi, U. I., Shouqat, U., \& Raza, A. (2016). Impact of Compensation Discrimination on Employees Performance in Engro Food Limited, Alhamd Food Limited and Leader industry Sahiwal of Pakistan. International Review of Management and Business Research, 5(2), 547. 
2. Anit, S. (2006). The effects of leadership style and team process on performance and innovation in functionally heterogeneous teams. Journal of Management 32: 132.

3. Biswas, S. (2009). HR Practices as a Mediator Between Organizational Culture and Transformational Leadership: Implications for Employee Performance.

4. Blazovich (2013). Team identity and performance - based compensation effects on performance. Team Performance Management, Vol. 19, No.3/4, 153-184.

5. Carnahan Seth, Agarwal, Campbell, and Franco. (2010). The Effect of Firm Competation Structures on Employee Mobility and Employee Enterpreneurship of Extreme Employers. CES. 10(06): 1-40.

6. Fernandes, C., \& Awamleh, R. (2009). The Impact of Transformational Leadership Style on Employee's Satisfaction and Performance: An Empirical Test in a Multicultural Environment. International Business \& Economics Research Journal.

7. Ganapathi and Prasad. (2008). Effects of working environment on the performance of executives. Asia-Pacific Business Review, Vol. IV, No.3, 117-123.

8. Ganapathi and Prasad. (2008). Effects of working environment on the performance of executives. Asia-Pacific Business Review, Vol. IV, No.3, 117-123.

9. Guo, W. C., Shiah-Hou, S. R., \& Yang, Y. W. (2006). Stock bonus compensation and firm performance in Taiwan. Managerial finance, 32(11), 862-885.

10. Kuludong, F. (2016). Pengaruh Communication Skill Dokter Terhadap Kepuasan Pasien yang dimoderasi oleh Implicit Self Theorist (Studi Mayapada Hospital Jakarta Selatan).Tesis. Jakarta: Universitas Esa Unggul.

11. Malik, M. I., Ahmad, A., Gomez, S. F., \& Ali, M. (2011). A study of work environment and employees' performance in Pakistan. African Journal of Business Management, 5(34), 13227.

12. Philip, Stacey \& Ling Tsai. (2010). The Impact of Job Mobility, Hourly Compensation, \& Work Hours on Job Satisfaction. Institute for Research in Training \& Development.

13. Shea, C.M. (1999). The effects of leadership style on performance improvement on a manufacturing task. The Journal of Business, Vol.72, No.3, 407-422.

14. Shieh. (2008). Effect of corporate compensation design on organizational performance. Social Behavior and Personality, 36 (6), 827-840.

15. Shieh. (2008). Effect of corporate compensation design on organizational performance. Social Behavior and Personality, 36 (6), 827-840.

16. Sinclair (2004). The effect of director compensation on firm performance. Temple University, Doctoral Dissertation Approval on Behalf of the Graduate Board.

17. Sugiyono. (2013). Statistika Untuk Penelitian. Bandung: Alfbeta.

18. Warrick, D. D. (1973). The effect of leadership style and adaptability on employee performance and satisfaction.

19. Yukl, G. (2009). Kepemimpinan dalam Organisasi. Jakarta : PT Indeks Kelompok Gramedia. 